\title{
PENGARUH FRAKSI AIR EKSTRAK RIMPANG TEMU MANGGA TERHADAP EKSPRESI Ki67 PADA GALUR SEL KARSINOMA KOLON HT-29
}

\author{
DiahAndriana \\ Fakultas Kedokteran Universitas Islam Malang \\ E-mail : andriana_2209@yahoo.com
}

\begin{abstract}
The incidence rate of colon carcinoma in Indonesia has recently showed significant increase. The management of colon carcinoma has gained a lot from the result of bimolecular studies.This study is aimed as determining the effect of extracted fraction of Temu Mango (Curcuma Mango, Val) on the suppression of Ki67 expression, a protein known as cell proliferation marker. This study was conducted in vitro on HT-29 colon cancer by observing the expression of Ki67.

HT-29 colon cancer cell was cultured with the mixture of RPMI 1640 media, 1\% fungi zone, and $1 \%$ antibiotic on $37^{\circ} \mathrm{C}$ and $5 \% \mathrm{CO}_{2}$ concentration. Samples were divided into two groups: the TemuMangga group as a positive control and 5-FU group as a negative control.Each group was cultured with 1640 RPMI added with extracted fraction of TemuMangga or 5-FU with concentration series each under $L C_{50}$. Quantification of culture result was done by observing the Ki67 expression presented in cell percentage.

This study demonstrated that 5-FU on $150 \mu \mathrm{g} / \mathrm{ml} ; 75 \mu \mathrm{g} / \mathrm{ml} ; 37,5 \mu \mathrm{g} / \mathrm{ml}$; and $18,75 \mu \mathrm{g} / \mathrm{ml}$ concentration and extracted fraction of Temu Mango on $0,125 \mu \mathrm{g} / \mathrm{ml} ; 0,0625 \mu \mathrm{g} / \mathrm{ml} ; 0,03125 \mu \mathrm{g} / \mathrm{ml}$ and $0,015625 \mu \mathrm{g} / \mathrm{ml}$ express the suppression of Ki67 expression respectively.

Extracted fraction of Temu Mango and 5-FU has the potential of suppressing Ki67 expression. The Ki67 suppression between Temu Mango extract and 5-FU showed no significant difference.

Key words: Temu Mango extract (Curcuma mangga, Val); 5-FU; Ki67 expression.
\end{abstract}




\begin{abstract}
ABSTRAK
Angka kejadian kanker kolon di Indonesia dewasa ini menunjukkan peningkatan yang cukup berarti.Penatalaksanaan kanker kolon telah banyak memanfaatkan temuan ilmiah hasil kajian molekuler. Penelitian ini dilaksanakan untuk mengetahui pengaruh fraksi air ekstrak temu mangga (Curcuma mangga,Val) terhadap penekanan ekspresi Ki67 yaitu suatu protein yang berfungsi sebagai marker proliferasi sel. Penelitian ini dilakukan in vitro terhadap kanker kolon HT-29 dengan melihat ekspresi Ki67.

Kultur sel kanker kolon HT-29 dilaksanakan dengan media RPMI 1640, 1\% fungizone dan $1 \%$ antibiotik pada suhu $37^{\circ} \mathrm{C}$ dan konsentrasi $\mathrm{C}_{2} 5 \%$. Sampel dibedakan dalam 2 kelompok perlakuan yaitu kelompok temu mangga sebagai kontrol (+) dan kelompok 5-FU sebagai kontrol (-). Masing-masing kelompok dikulturkan dengan RPMI 1640 lengkap ditambah dengan ekstrak temu mangga fraksi air atau 5-FU dengan serial konsentrasi masing-masing dibawah LC50. Dari hasil kultur kemudian dilihat ekspresi Ki67 yang ditampilkan dalam bentuk prosentase sel.

Hasil penelitian menunjukkan bahwa pemberian 5-FU pada konsentrasi $150 \mu \mathrm{g} / \mathrm{ml}$, $75 \mu \mathrm{g} / \mathrm{ml}, 37,5 \mu \mathrm{g} / \mathrm{ml}, 18,75 \mu \mathrm{g} / \mathrm{ml}$ dan pemberian temu mangga fraksi air pada konsentrasi 0,125 $\mu \mathrm{g} / \mathrm{ml}, 0,0625 \mu \mathrm{g} / \mathrm{ml}, 0,03125 \mu \mathrm{g} / \mathrm{ml}, 0,015625 \mu \mathrm{g} / \mathrm{ml}$ menunjukkan ekspresi Ki67 yang makin menurun dengan meningkatnya dosis. Dapat disimpulkan bahwa fraksi air ekstrak temu mangga dan 5-FU berpotensi menurunkan tingkat ekspresi Ki67.
\end{abstract}

Kata kunci : Ekstrak temu mangga (Curcuma mangga,Val), 5-FU, ekspresi Ki67

\section{PENDAHULUAN}

Karsinomakolonmerupakankeganasank etigaterbanyak di duniadansebagaipenyebabkematianked uaterbanyak (terlepasdari gender) di AmerikaSerikat.

Karsinomakolonmemilikiinsidensidanan gkakematian yang cukuptinggi di negara-

negaraberkembang.Angkakejadian yang pastidarikarsinomakolon di Indonesia belumada,

tetapikarsinomakolonmasukdalam 10

jeniskankertersering. Evaluasi data DepartemenKesehatanRepublik

Indonesia padatahun 1986 mendapatkanangkakejadian 1,8setiap 100.000 penduduk. Berdasarkan data histopatologikkanker di Indonesia tahun 1996 dan 1999, karsinomakolonmenempatiurutan ke-9 yaitusebanyak $3,11 \%$ dan $3,33 \%$. (KKAK, 2004., YKI, 1999., Helena, 1997., Alfred, 1997., Kodner, 1999).
Kemajuanilmupengetahuandantekn ologi di bidangkedokterankhususnyabidangbiol ogimolekuler yang sangatpesat, mempengaruhitatacarapenanganankarsi nomakolon, mulaidarideteksidini, diagnostik, terapi, prediksitingkatkeganasan, prognosis danpenanganantindaklanjut.

Pemeriksaanimunohistokimiadapatmem beriinformasimengenaikandunganberba gaiunsur protein di dalamsel normal maupunneoplastik.Pemeriksaanimunohi stokimiasebagaikelanjutanpemeriksaanr utinsemakinmeningkatpenggunaannya, karenainformasiberbagaiekspresi proteinspesifikdalamselneoplasmadapat dipakaisebagaisalahsatucarauntukmene ntukankeganasan,

pemilihanmetodeterapisertaprognosisny a(Ashariati, 2004., Allen 1995., Norton, 2000). Salah satupetanda tumor adalah Ki67.Ki67 merupakan protein spesifik yang 
keberadannyamelimpahpadasaatterjadi pembelahansel, sehingga Ki67 mudahdideteksipadapertumbuhansel normal maupunpadasel tumor.Pemeriksaansecaraimmunohistok imiaterhadap

Ki67

padakarsinomakolondenganmenggunak anmetoda Ki-67 labeling index menunjukkanbahwapeningkatan level Ki67 berhubungandengankualitashidup yang buruk, danpadakarsinomakolonbisadigunakans ebagaipetandauntukmenentukanperke mbangan tumor (Maltzman,2002.,Vilar, 2007., Oshima,2007).

Selainprosedurbakusecaramedis, banyakcara yang dilakukanpenderitauntukmencarikesem buhandaripenyakitkanker,

salahsatunyadenganmenggunakantana manobat.

Meskipunsecaraempirispotensidaritana manobattersebutdalammenghambatprol iferasiselkankerbelumterujisecarailmiah. Banyakjenistemumangga yang sudah lama dikenalsebagaiobat anti kanker, beberapasudahdiisolasikandungannyam enjadiobatkemopreventifdankemoterapi (Adijaya, 2006.,Katzung, 2001). Temumanggamengandungsenyawa protein mirip ribosome inactivating protein (RIPs) yang mempunyaiaktifitasmemotong DNA superkoil. Secara in vitro ekstrakkasar Curcuma

manggamempunyaiefeksitotoksikterhad ap B-LCL(B-limphoblastoid Cell Lines) danlimfosit normal yang diberikanekstrakkasartemumanggadan menunjukkanbahwapersentaseefeksitot oksikpadaselkankerlebihtinggisecarasig nifikandibandingsel

Normal(Sismindari,2003).

5-FU merupakanagenkemoterapi yang potenuntukkarsinomakolondansaatinisu dahsecaraluasdigunakanbaiksebagaiage ntunggalmaupunkombinasidenganagen kemoterapi yang lain. 5-FU merupakansenyawa anti metabolit, yaitusenyawa yang secarastrukturalmemilikikemiripandeng anmolekulendogenus.Dalamhalinimolek ulendogenus yang miripdengan 5-FU adalahbasa nitrogen dari DNA.Senyawainimampuberperandalam jalurmetabolisme yang diperankanolehsenyawa yang ditirunya.5-FU berperandalammenghambatsintesaasam nukleat (Polymerase DNA) padafase $S$ (Pecorino, 2005).

Berdasarkanuraian di atasdianggapperludilakukanpenelitianuj ilaboratorikpotensifraksi air ekstrakrimpangtemumangga (Curcuma mangga, $\mathrm{Val}$ )

dalampenghambatanekspresi Ki67 suatu marker proliferasisel, denganmenggunakangalurselkarsinoma kolon HT2-9 secara in vitro. 5-FU sebagaikemoterapitertuadigunakanseba gaipembandingsecaradeskriptifterhadap ekstraktemumangga.Penelitianinidihara pkandapatmemberikaninformasi yang bergunabagikajianterapikomplementer molecular target therapy di masa yang akandatangataupenemuankandidatanti tumor yang berasaldariekstraktemumanggaMETOD E PENELITIAN

\section{Rancangan penelitian}

Penelitian ini berupa penelitian analitik eksperimental laboratorik. Subyek penelitian adalah galur cell kanker kolon HT-29.Penelitian dilakukan selama 3 bulan

\section{Kultur Sel}

Kultur sel HT-29 dilakukan setelah thawing dari tangki nitrogen cair, sel selanjutnya dikultur pada media RPMI 1640, FBS 10\%, Penstrep 2\%, Fungizone $0,5 \%$ setelah konfluent sel dipanen dengan tripsin $0,25 \%$.

\section{Starvasi}


Tujuan langkah ini adalah mencapai keseragaman umur sel HT-29 dalam kultur. Dalam menggunakan RPMI 1640, FBS 0,5\%, Penstrep 2\%, Fungizone $0,5 \%$, selama 7 hari setiap 3 hari sekali media diganti dengan yang baru.

\section{Imunositokimia}

Biakan sel HT-29 pada media murni dan setelah diberi perlakuan dengan ekstrak rimpang temu mangga serta 5-FU pada konsentrasi dibawah $\mathrm{LC}_{50}$, dan 3 serial di bawahnya dikulturkan pada media RPMI 1640. 1\% Amphotricin, 2\% penstrep, 10\% FBS diteteskan dengan 24 well yang dilengkapi dengan plastic cover slips dengan diameter $1,3 \mathrm{~cm}$. Setelah 3 hari diperlakukan dengan konsentrasi temu mangga $0,125 \mathrm{ug} / \mathrm{ml}$, $0,0625 \mathrm{ug} / \mathrm{ml}, \quad 0,03125 \mu \mathrm{g} / \mathrm{ml}$, $0,0151625 \mu \mathrm{g} / \mathrm{ml}$ dan 5-FU dengan konsentrasi $\quad 150 \mathrm{ug} / \mathrm{ml}, \quad 75 \mathrm{ug} / \mathrm{ml}$, $37,5 \mathrm{ug} / \mathrm{ml}, \quad 18,75 \mathrm{ug} / \mathrm{ml}, \quad$ pada konsentrasi $5 \% \mathrm{CO} 2$ dan suhu $37^{\circ} \mathrm{C}$ (dalam inkubator). Setelah itu media diambil dan diganti dengan PBS formalin $10 \%$ selama 30 menit. Kemudian PBS diambil dan dicucidenganAquadestkemudianditaba h metanol dan 0,3\% $\mathrm{H}_{2} \mathrm{O}_{2}$ selama 30 menit. PBS formalinselanjutnyadiambil dan

dicucidenganAquadestkemudianditamb ahkan metanol selama 30 menit.Welldicucidengan PBS 2x5 menit. Dilakukanblockingdengan normal serumselama 20 menit, diinkubasidenganantibodi Ki67 selama 18 jam pada $4^{\circ} \mathrm{C}$. Dicucidenganwashing buffer (PBS) 2 kaliselanjutnyadiinkubasi 20 menitdenganpolyvalent universal HRP conjugate. Dicucidengan PBS 2 kaliselanjutnyadiinkubasidengan DAB (DeaminoBenzidin) sebagaisubtratensim. Pewarnaantanding (counterstain) digunakanHematoxilin Mayer. Pengamatandilakukandenganmikrosko
pcahayaOlympus DP40.

Penilaianmaknatampilanekspresi Ki67 dinyatakansebagaiprosentasesel yang dihitungberdasarkantampilanpositifdari ki67.

\section{Pembuatan Temu mangga fraksi air}

ekstraksi temu mangga fraksi air berbentuk larutan. Dalam penelitian digunakan temu mangga fraksi air murni (Curcuma mangga,Val), yang dibuat dari 100gr serbuk rimpang temu mangga yang dioven selama 3 jam dengan suhu $60^{\circ}$ sehingga kadar air $0 \%$, kemudian diencerkan dengan $1000 \mathrm{ml}$ aquabidest dan dipanaskan sehingga mendidih selama 15 menit sehingga tinggal $200 \mathrm{cc}$ dan disaring dengan filter paper mesh dengan porositas $20 \mu \mathrm{m}$ dan ditimbang sekitar 90 gr.

\section{Ekspresi Ki67}

ekspresi protein Ki67 yang terdapat pada inti sel kanker kolon HT29 sebagai hasil pengecatan imunostaining dengan metode avidin-biotin-complex menggunakan mouse anti human Mo $\mathrm{Ab}$ Ki67. Sistem enzimatis yang digunakan adalah peroksidase substrat enzim DAB. Nilai tampilan Ki67 dinyatakan sebagai prosentase sel.

\section{Proliferasi sel}

Proliferasi sel dihitung setelah 24 jam inkubasi pada suhu $37^{\circ} \mathrm{C}$ dan dilakukan penghitungan jumlah sel secara direct counting menggunakan mikroskop inverted dan bilik hitung Improved Neubeuer haemocytometer. Prosentase sel mati ditentukan dengan banyaknya prosentase sel yang menyerap warna Triphan blue.

\section{Analisis data}

Data yang diperoleh dalam penelitian, dilakukan uji normalitas data dengan menggunakan uji Kolmogorov-Smirnov. Untuk mengetahui kemampuan fraksi air ekstrak rimpang temu mangga (Curcuma mangga,Val) dan 5-FU dalam menghambat pertumbuhan sel kanker kolon HT-29 menggunakan uji statistik 
korelasi regresi. Uji korelasi regresi dilaksanakan untuk mengetahui:

1. pengaruh pemberian baik 5-FU maupun ekstrak temu mangga fraksi air terhadap penghambatan proliferasi sel kanker kolon HT-29.

2. Pengaruh pemberian 5-FU maupun ekstrak temu mangga fraksi air terhadap tingkat ekspresi Ki67 sel kanker kolon HT-29.

Untuk mengetahui profil perbedaan pengaruh penekanan ekspresi Ki67 antara fraksi air ekstrak temu mangga (Curcuma mangga,Val) dengan 5-FU dilakukan secara deskriptif, karena konsentrasi fraksi air temu mangga dan 5-FU tidak sama sehingga tidak dapat dibandingkan secara analitik.

\section{HASIL PENELITIAN}

Penentuan Level Ekspresi Ki67 Akibat Pemberian Fraksi air Ekstrak Temu Mangga (Curcuma mangga, Val) pada Kultur Sel Karsinoma Kolon HT-29

Kultur dengan perlakuan fraksi air temu mangga(Curcuma mangga, $\mathrm{Val}$ )setelah ditentukan konsentrasi $\mathrm{LC}_{50}$, selanjutnya dilakukan kultur sel karsinoma kolon HT-29 pada konsentrasi LC 50 yaitu 0,125 $\mu \mathrm{g} / \mathrm{ml}$ dan 3 serial konsentrasi di bawahnya sehingga perlakuan yang diberikan menggunakan konsentrasi fraksi air temu mangga sebagai berikut: $0,125 \mu \mathrm{g} / \mathrm{ml}$, 0,0625ug/ml, 0,03125ug/ml, 0,01563 ug/ml, Pemeriksaan imunositokimia dengan menggunakan monoklonal antibodi primer anti-Ki67. Ekspresi positif kuat dari Ki67 ditunjukkan dengan adanya granula kecoklatan pada inti sel, sedangkan sel yang negatif tidak menampakkan adanya granula kecoklatan tersebut. Prosentase sel karsinoma kolon HT-29 yang positif mengekspresikan Ki67 ditentukan dengan melakukan pengamatan menggunakan mikroskop cahaya
OLYMPHUS BX-41 dengan pembesaran 400x pada 9 lapang pandang. Hasil pengamatan sebagaimana ditampilkan dalam gambar berikut ini:

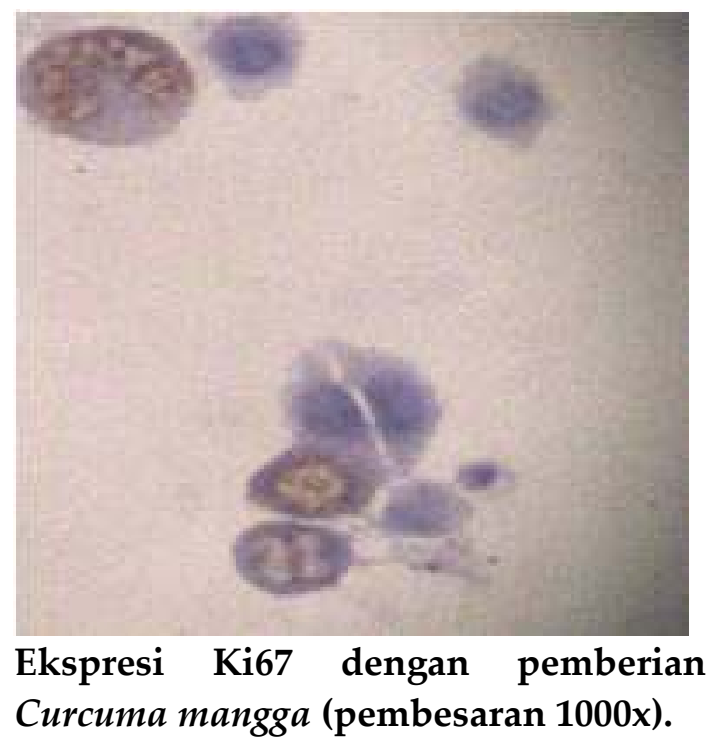

Berdasarkan hasil pengamatan sitologi tersebut dapat ditentukan nilai kuantitatif ekspresi Ki67 yang dinyatakan dengan prosentase sel, untuk masing-masing sampel adalah sebagai berikut:

Prosentase tampilan Ki67 pada sel karsinoma kolon HT29 dengan perlakuan fraksi air ekstrak temu mangga (Curcuma mangga,Val).

\begin{tabular}{|c|c|c|}
\hline No & SAMPEL & $\%$ \\
\hline 1 & $\begin{array}{l}\text { Temu mangga } \\
0,125 \mathrm{ug} / \mathrm{ml}\end{array}$ & 5,22 \\
\hline 2 & $\begin{array}{l}\text { Temu mangga } \\
0,0625 \mathrm{ug} / \mathrm{ml}\end{array}$ & 13,44 \\
\hline 3 & $\begin{array}{l}\text { Temu mangga } \\
0,03125 \mathrm{ug} / \mathrm{ml}\end{array}$ & 21,11 \\
\hline 4 & $\begin{array}{l}\text { Temu mangga } \\
0,01563 \mathrm{ug} / \mathrm{ml}\end{array}$ & 27,67 \\
\hline
\end{tabular}

Data tersebut ditampilkan dalam bentuk histogram sebagai berikut: 


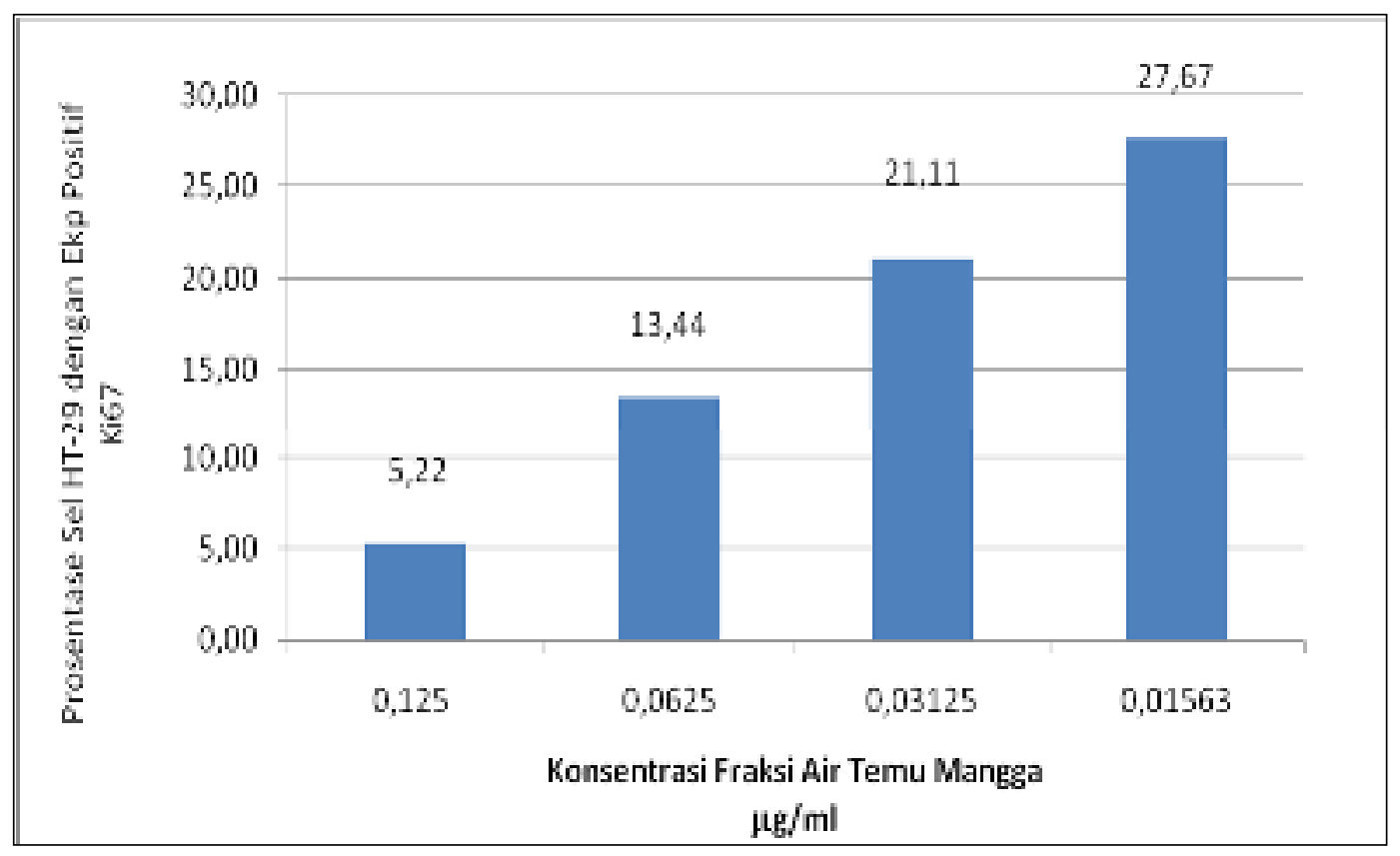

tampilan ekspresi Ki67 pada sel karsinoma kolon HT-29 pada berbagai serial konsentrasi perlakuan dengan ekstrak temu mangga(Curcuma mangga,Val).

Penentuan Level Ekspresi Ki67 akibat Pemberian 5-FU pada Kultur Sel Karsinoma Kolon HT-29.

Konsentrasi 5-FU yang digunakan dalam kultur sel karsinoma kolon HT-29 adalah: $150 \mu \mathrm{g} / \mathrm{ml}, 75 \mu \mathrm{g} / \mathrm{ml}, 37,5 \mu \mathrm{g} / \mathrm{ml}$ dan $18,75 \mu \mathrm{g} / \mathrm{ml}$. Hasil kultur kemudian dilakukan pemeriksaan imunositokimia dengan menggunakan monoklonal antibodi primer anti-Ki67. Deteksi ekspresi Ki67 dilaksanakan dengan metode $\mathrm{ABC}$ (Avidin biotin Complex) dengan hasil sebagaimana ditampilkan pada gambar berikut ini:

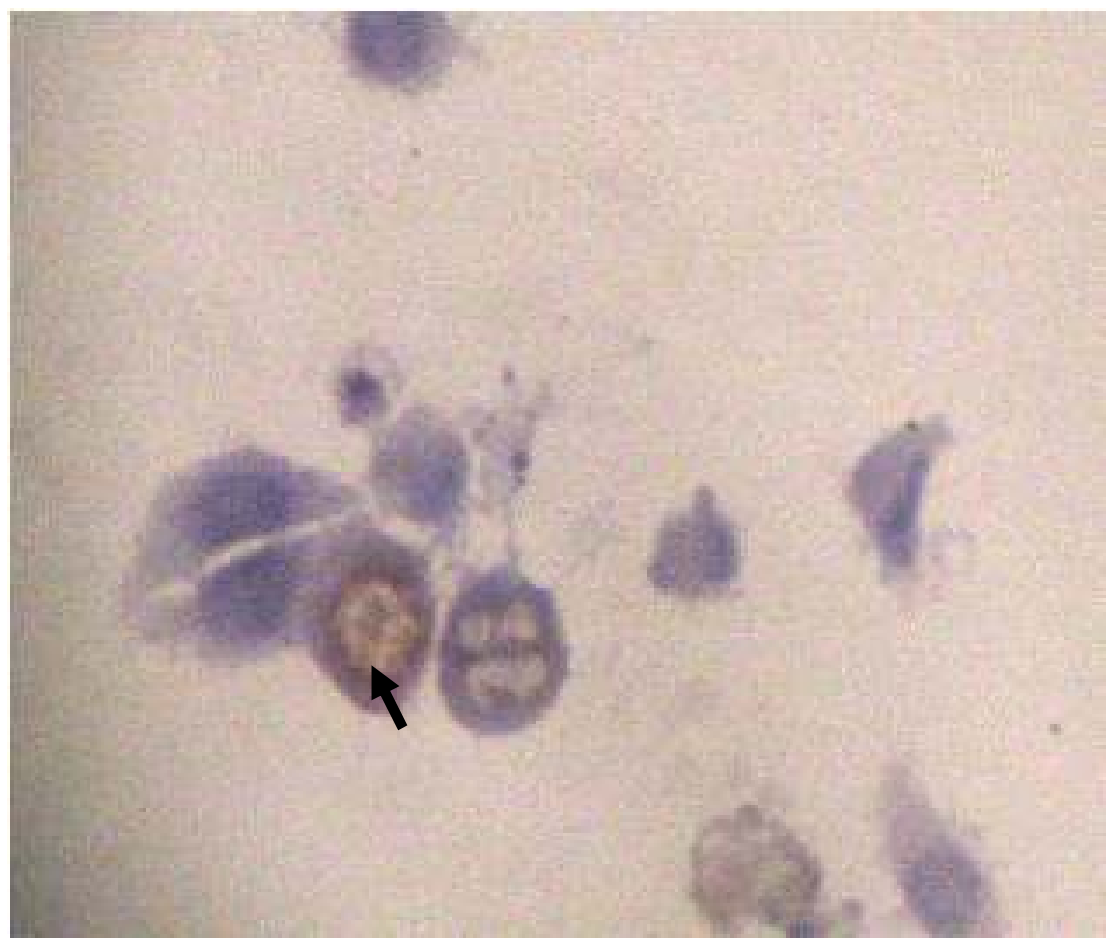


Tampilan ekspresi Ki67 pada sel karsinoma kolon HT-29 pada berbagai serial konsentrasi perlakuan dengan ekstrak temu mangga(Curcuma mangga, Val).

Ekspresi Ki67 dengan pemberian 5-FU ditunjuk anak panah (perbesaran 1000x).

Berdasarkan hasil pengamatan imunositokimia tersebut dapat ditentukan nilai kuantitatif ekspresi Ki67 yang dinyatakan dengan prosentase sel, untuk masing-masing sampel adalah sebagai berikut:
Prosentase tampilan Ki67 pada sel karsinoma kolon HT-29 dengan perlakuan 5-FU

\begin{tabular}{ccc}
\hline No & SAMPEL & $\%$ \\
\hline 1 & 5-FU 150 ug/ml & 7,00 \\
\hline 2 & 5-FU 75 ug/ml & 19,00 \\
\hline 3 & $5-F U ~ 37,5 \mathrm{ug} / \mathrm{ml}$ & 25,56 \\
\hline 4 & 5-FU 18,75 ug/ml & 28,11 \\
\hline
\end{tabular}

Hasil di atasditampilkandalambentuk histogram sebagaiberikut:

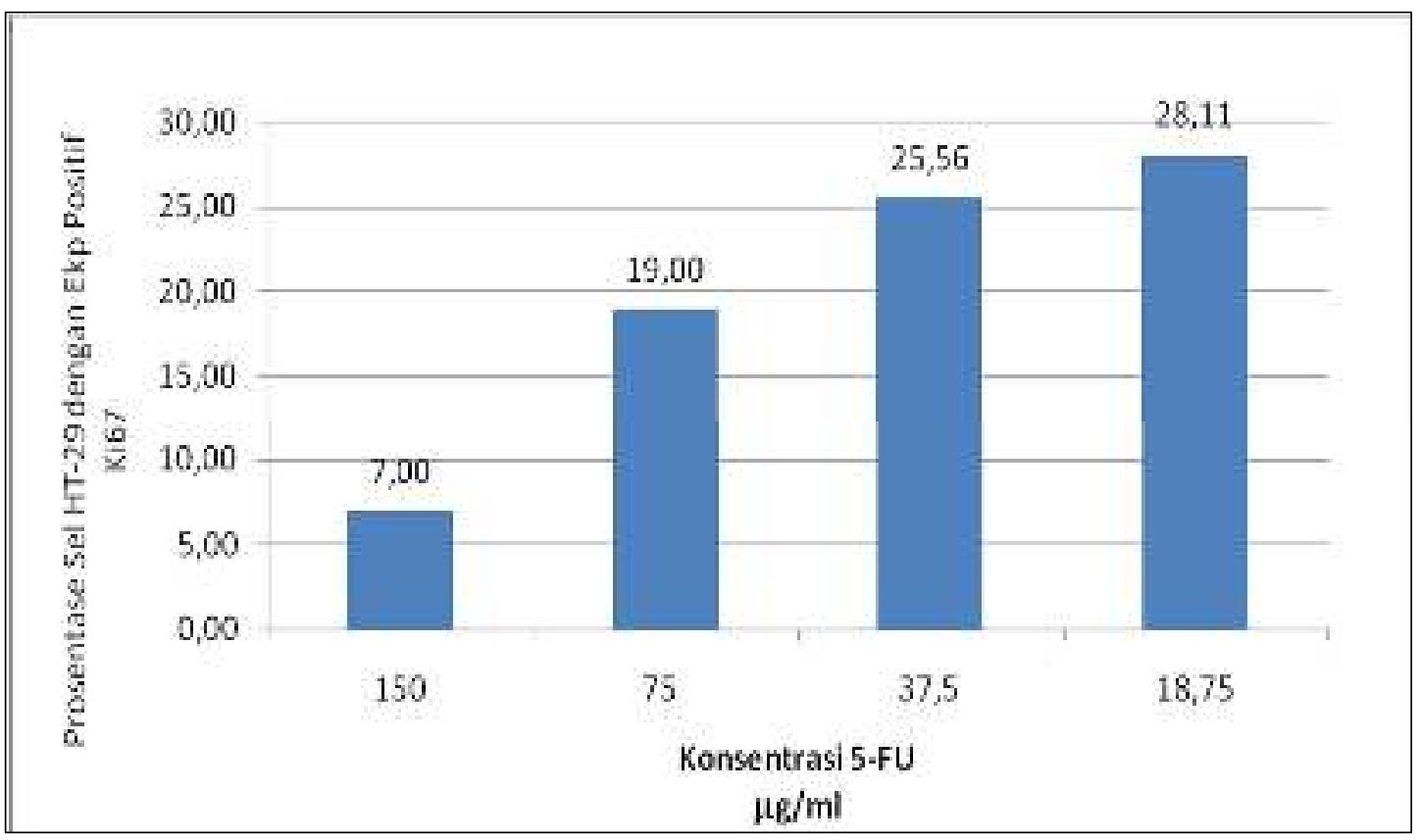

Profil tampilan ekspresi Ki67 pada sel karsinoma kolon HT-29 pada perlakuan dengan 5 -FU.

\section{PEMBAHASAN}

Ki67 adalah protein inti, bisa dideteksi dengan mudah pada sel sedang aktif membelah, sehingga keberadaan protein ini bisa digunakan untuk mendeteksi kecepatan pertumbuhan tumor (Maltzman, 2002). Ki67 bisa digunakan sebagai marker untuk proliferasi sel(Kanai, 2009). Antigen Ki67 bisa dideteksi dalam inti sel pada fase interfase. Fase mitosis sebagian besar protein direlokasi ke permukaan khromosom. Ki67 didapatkan pada semua fase pada siklus sel ( G1, S, G2, dan mitosis), tetapi tidak didapatkan pada fase resting cells (G0)(Scholzen,2000)

Zat aktif dari temu mangga adalah minyak atsiri, amilum, tanin, gula dan damar (Anonim,1988). Minyak atsiri Curcuma mangga Terdiri dari 4 komponen utama yaitu yang 
teridentifikasi sebagai $\alpha$-pinene $(1,71 \%)$, $\beta$-myrcene $(19,74 \%)$, geranyl alcohol $(76,24 \%)$ dan bicyclo 3.1.1 heptan 3-ol $(2,31 \%)$ (Khasanah, 2002). Curcuma mangga mengandung senyawa protein mirip ribosome inactivating protein (RIPs)yang mempunyai aktifitas memotong DNA superkoil(Sismindari,2003). Beberapa tumbuhan mengandung protein yang disebut sebagai (RIPS) yang merangsang aktifitas dari enzim $R N A N$-glycosidase dan adenosine glikosidase, sehingga mampu menghentikan siklus sel.

Dari hasil penelitian ini menunjukkan bahwa penurunan prosentase sel karsinoma kolon HT-29 yang positif mengekspresikan Ki67 berasosiasi dengan pengikatan konsentrasi fraksi air temu mangga(Curcuma mangga,Val). Hasil uji korelasi regresi terhadap peran fraksi air ekstrak temu mangga (Curcuma mangga,Val) terhadap ekspresi ki67 mengikuti persamaan linier $\mathrm{Y}=22,092-0,105 \mathrm{X}$ dengan koefisien korelasi $\mathrm{R}=0,994$ yang menunjukkan bahwa fraksi air ekstrak temu mangga mampu menurunkan ekspresi Ki67 secara signifikan. Pengembangan obat antikanker yang didasarkan pada regulasi siklus sel selanjutnya diarahkan pada penghambatan terjadinya proses pembelahan sel sehingga senyawa atau protein yang diberikan pada penderita dapat mencegah sintesis DNA dan mitosis sehingga menghentikan proliferasi sel kanker.

RIPs protein memiliki aktivitas ensim $\mathrm{N}$ glikosidase, dan polinucleotide: adenosine glycosidase(PAG), serta memilika aktifitas DNAse like dan phosphatase, dan mampu meningkatkan aktifitas enzim RNA Nglikosidase pada konsentrasi yang sangat rendah sehingga mampu menghentikan siklus sel terutama pada fase G1(Willy,2001). Hal ini kemungkinan terjadi juga pada kultur sel karsinoma kolon HT-29 dengan perlakuan fraksi air ekstrak temu mangga, sehingga terjadi penghentian siklus sel pada fase G1 sebelum terbentuk cyclin $E$, sehingga siklus sel tidak bisa berlanjut sampai ke fase $\mathrm{S}$ dan fase selanjutnya.

Penurunan prosentase sel karsinoma kolon HT-29 yang positif mengekspresikan Ki67 berasosiasi dengan pengikatan konsentrasi 5-FU mengikuti persamaan $\mathrm{Y}=31,335-24,375$ dengan koefisien korelasi $R=1,00$, menunjukan bahwa terjadi penurunan ekspresi Ki67, yang menggambarkan terjadinya penurunan proliferasi sel. 5FU digunakan pada penelitian ini karena 5-FU merupakan agen kemoterapi yang poten untuk karsinoma kolon dan saat ini sudah secara luas digunakan baik sebagai agen tunggal maupun kombinasi dengan agen kemoterapi yang lain.

Hasil penelitian menunjukan bahwa terdapat penurunan ekspresi Ki67 yang bermakna pada perlakuan menggunakan fraksi air ekstrak temu mangga maupun 5-FU dan pemberian 5FU maupun fraksi air ekstrak temu mangga dengan konsentrasi yang berbeda memberikan pengaruh yang nyata dalam penurunanan ekspresi Ki67 pada sel karsinoma kolon HT-29 secara in

vitro.Penurunanproliferasiselinidisebabk anpenghambatansintesa DNA. 5-FU adalahagenkemoterapi yang bersifat anti metabolit, artinya secara biologis 5-FU berfungsimenghalangiterbentuknyadTM $P$ (deoxyTimidin mono Phosphat)suatumonomer DNA yang pembentukannyamelibatkanenzimTymi dilatSyntetase. Karenaadanya 5-FU makadTMPtidakterbentuk, enzimTymidilatSyntetaseterhambatoleh 5-FU sehinggaterbentukFdeoxyuridylate(F-dUMP).

Telahdiketahuibahwamonomer DNA butuhdTTP(deoxyTymidinTri-phosphat), dAMP(deoxyAdenosineTri-Phosphat), 
dCTP(deoxyCitosineTri-Phosphat) dan dGTP(deoxyGuanidineTri-

Phosphat)sehinggaakanmenghalangipoli merisasidNTPsmenjadi DNA.(Pecorino, 2005)..Dengantidakterbentuknya DNA makatidakadatranskripsi RNA sehinggasintesaproteintidakberlangsung , tidakterbentukselanakanbaru, dengan kata laintidakadaproliferasisel. Halinisesuaidenganmenurunnyatingkat ekspresi Ki67 pada pemberian 5-FU pada kultursel, mampumenghambatproliferasiselkarsin omakolon HT-29.

\section{Kesimpulan}

ekstrak temu mangga fraksi air menekan ekspresi Ki67 pada sel kanker kolon HT-29 secara in vitro. Semakin tinggi dosis yang diberikan ekspresi Ki67 semakin menurun.

\section{Saran}

1. Disarankan untuk dilakukan penelitian terhadap ekspresi Ki67 pada galur sel karsinoma kolon yang lain atau penelitian secara in vivo dengan konsentrasi pada $\mathrm{LC}_{50}$ dan atau di bawahnya.

2. Disarankan untuk dilakukan penelitian dalam bidang biologi molekuler lebih lanjut mengenai pengaruh ekstrak temu mangga khususnya fraksi lain terhadap penghambatan proliferasi sel karsinoma kolon HT-29. 


\section{DAFTAR PUSTAKA}

Alfred M.C., Bruce D.M., 1997, Cancer of The Colon, In : Cancer, Principles and Practice of Oncology, $5^{\text {th }} \mathrm{Ed}$, Editors : Devita V.T., Lippincott Raben, Philadelphia, pp. $1144-85$

Allen J.I., 1995, Molecular Biology of Colorectal Cancer : a Clinician's View, Perspect Colon Rectal Surgery, 8, pp. $181-202$

American Joint Committee on Cancer (AJCC), 1992, Manual for Staging of Cancer, $4^{\text {th }}$ Edition, Philadelphia, pp. 82

Arief

T.Q.M., 2004

PengantarMetodologiPenelitianun tukIlmuKesehatan,

CetakanKedua, Penerbit CSGF, Klaten

Ashariati A., 2004, Adjuvant Chemotherapy of Colorectal Cancer, In: Recent Advances and Challenges In General Surgeons in Indonesia, Surabaya

Budiani D.R.2006, Expression of LMP1 in Javanese Colon Carcinoma Patient's with Duke's Classification System : Indicated The Association of EpsteinBarr Virus Infection In Colon Malignancies, Department of Patology Anatomy, Medicine Faculty of SebelasMaretUniverity, UNS Press, Surakarta

Cancer Researh UK, 2007, Chemotherapy Drugs For Bowel Cancer,

http://survey.cancerresearchuk.org

Carlos C.C., 2004, p53 and RB : Simple Interesting Correlates or Tumors Markers of Critical Predictive Nature?, Journal of Clinical Oncology. Vol. 22. No. 8, Memorial-Kettering Cancer Center, New York, pp. 975 7

Chung-Faye G.A., Kerr J.D., 2000, $A B C$ of Colorectal Cancer : Innovative Treatment for Colon Cancer, BMJ : 321 , pp. 1397 - 99
Compton C.C., 2005, The Staging of Colorectal Cancer : 2004 and Beyond, Ca Cancer Journal for Clinicians, Vol. 54. No. 6, pp. $295-308$

Helena R.C., Kirby I.B., 1997, Tumors of the Colon, In: Maingot's Abdominal Operations, Volume II, 10 $10^{\text {th }} \mathrm{Ed}$, Editors :Zinner M.J., et al., Appleton \& Lange, Conecticut, pp.1281-301

Irene M.G., Thomas E.W., 2005, Targeting Apoptosis Pathways in Cancer Therapy,

Janne P.A., 2000, Chemoprevention of Colorectal Cancer, The New England Journal of Medicine, Vol. 342. No. 26, pp. $1960-66$

Katzung B.G., 2001, Basic \& Clinical Pharmacology, $8^{\text {th }}$ Ed, McGraw-Hill Companies, Philadelphia

KelompokKerjaAdenokarsinomaKolore ktal, 2004, PanduanPengelolaanAdenokarsino maKolorektal,pp. 1 - 49

King M.W., 2004, Tumor Suppressors and Cancer, IU School of Medicine, Sergio Marchesini, pp. 1 - 11

Kodner I.J., Robert D.F., 1999, Colon, Rectum, and Anus, In : Principles of Surgery, $7^{\text {th }}$ Ed, Vol. 2, Editors : Schwartz I.S., McGraw-Hill Health Professions Division., New York, pp. $1265-380$

Murti

B., 1996, PenerapanMetodeStatistikNonpara metrikuntukIlmu-ilmuKesehatan, GramediaPustakaUtama, Jakarta, pp. 37

Murti

B., 2006, DesaindanUkuranSampeluntukPen elitianKuantitatifdanKualitatif di Bidangkesehatan, GadjahMada University Press, Yogyakarta

Norton J.A., et al., 2000, Surgery Basic Science and Clinical Evidence, Part 1, Springer, New York, pp. $702-4$

Phillips J., 1997, The Biology of the Disease, Blacwell Science, Oxford, pp. 429 587 
Priyanto, 2007. Toksisitas Obat, Zat Kimia dan Terapi Antidotum,I:131

Pusztai L., et al., 1996, Cell Proliferation in Cancer; Regulatory Mechanisms of Neoplastic Cell growth, Oxford University Press, New York

Rickwood D., Harris J.R., 1996, Cell Biology, Essential Techniques, Jhon Willey \& Sons Ltd, Chichester, pp. $38-66$

Shengli C., 2001, Cell Cycle and Tumor Suppressor Genes, Charles Cai Tech, edit Tom Beron, pp. $1-36$

Sigma A, 2007, HT29 Cell Line Human Colon Adenocarcinoma, http://sigmaaldrich.com

Sjamsuhidayat R., de Jong W., 1997, Buku Ajar IlmuBedah, EGC, Jakarta, pp. 876 - 99

Soetamto W.P., 2004, PembedahanKarsinomaKolondan

Rektum, In : Recent Advance and Challenges in General Surgeon in Indonesia, pp. $12-9$

Sudigdo S.A., Ismael S., 2002, Dasar DasarMetodologiPenelitianKlinis,

Ed. 2, SagungSeto, Jakarta

Suryadi H., Malik S.G., Sudoyo H., Marzuki S., 2004, Mitochondrial Medicine, Eijkman Lecture Series 2, Lembaga Eijkman, Jakarta, pp. 145 $-64$

Tannock I.E., Hill R.P., 1998, The Basic Science of Oncology, $3^{\text {rd }}$ Edition, McGraw Hill, Singapore

Teich N.M., 1997, Oncogenes and Cancer,In : Cellular and Molecular Biology of Cancer $3^{\text {rd }}$ Ed, Editors : Franks L.M., Teich N.M., Oxford University Press, New York, pp. $169-201$

Tjarta A., 2001, Neoplasia, Dalam : Patologi Umum,Sagung Seto, Jakarta, pp. $198-9$
Tjokronegoro A., Sudarsono S., 1999, Metodologi Penelitian Bidang Kedokteran, Cetakan ketiga, Fakultas Kedokteran Universitas Indonesia, Jakarta

Trigan, 2007, 5 Flurouracil ( 5-FU ), http://www.trigan.com/contact.ht $\mathrm{m}$

Yayasan Kanker Indonesia, 1999, Rangkuman Hasil Seluruh Pusat Patologi di Indonesia, Dalam : Kanker di Indonesia, Data Histopatologi

Yuwono T., 2005, Biologi Molekular, Penerbit Erlangga, Jakarta 